\title{
Critical incidents of trust erosion in leadership of head nurses ${ }^{1}$
}

\author{
Rodrigo Yañez-Gallardo² \\ Sandra Valenzuela-Suazo ${ }^{3}$
}

Investigations show that distrust towards head figures has a particularly negative effect on organizational dynamics. Because of this, the main types of behavior associated with distrust in nursing professionals with leadership duties have been identified, examining which aspect of reliability is most frequently related to distrust. Based on an analysis of 61 critical incidents, selected from 90 hospital employees, the most frequently mentioned behavior types related to distrust were "Public Abuse", "Not giving permission for time off for a special occasion" and especially an erosion of trustworthiness in the leader's integrity dimension. The implications of these findings are discussed, so that nursing professionals can avoid the development of distrust in interpersonal relationships and damage to the appropriate functioning of health services.

Descriptors: Trust; Nursing; Leadership.

\footnotetext{
${ }^{1}$ Supported by project Diuc 211.172.017-1.0, Universidad de Concepción, Chile.

${ }^{2}$ Psychologist, M.Sc. in Social Research and Development, Professor, Departamento de Psicología, Universidad de Concepción, Chile. E-mail: ryanez@udec.cl.

${ }^{3}$ RN, Ph.D. in Nursing, Professor, Departamento de Enfermería, Universidad de Concepción, Chile. E-mail: chile.svalenzu@udec.cl.
} 


\title{
Incidentes críticos de erosão da confiança na liderança de chefes de enfermagem
}

Algumas investigações mostram que a desconfiança nos chefes produz um efeito especialmente negativo nas dinâmicas organizacionais. Assim, identificamos os principais tipos de condutas associadas a desconfiar dos profissionais de enfermagem com cargos de chefes; também, examinaram-se quais dimensões da confiabilidade se relacionam mais frequentemente com a desconfiança. Baseando-se na análise de 61 incidentes críticos coletados em 90 funcionários de um hospital, identificou-se que os tipos de condutas que geravam mais frequentemente a menção de desconfiança eram acontecimentos de "Maus-tratos em público" e "Não dar uma permissão para algo especial"; e que se desgasta, especialmente, a confiabilidade do chefe na dimensão integridade. Discutem-se as implicações destes resultados para que os profissionais da enfermagem, que exercem a liderança, evitem o seu surgimento e o posterior desenvolvimento de desconfiança nas suas relações interpessoais, as que são prejudiciais para o adequado funcionamento dos serviços de saúde.

Descritores: Confiança; Enfermagem; Liderança.

\section{Incidentes críticos de erosión de la confianza en el liderazgo de enfermería}

\begin{abstract}
Investigaciones muestran que la desconfianza hacia las jefaturas tiene un especial efecto negativo en la dinámica organizacional. Por ello, se identificaron los principales tipos de conductas asociadas a desconfiar de profesionales de enfermería con cargo de jefatura y se examinó cual dimensión de la confiabilidad se relaciona más frecuentemente con la desconfianza. Basándose en el análisis de 61 incidentes críticos obtenidos de 90 funcionarios de un hospital, se identificó que los tipos de conducta que generaban más frecuentemente mención de desconfianza fueron "Maltrato en público" y "No dar un permiso para algo especial"; y que se erosiona especialmente la confiabilidad del jefe en la dimensión integridad. Se discuten las implicancias de estos hallazgos para que los profesionales de enfermería que ejercen liderazgo eviten el surgimiento y desarrollo de la desconfianza en sus relaciones interpersonales y no perjudiquen el apropiado funcionamiento de los servicios de salud.
\end{abstract}

Descriptores: Confianza; Enfermería; Liderazgo.

\section{Introduction}

Popular wisdom says that destroying is easier than constructing. This can also apply to the theme trust. Building trust demands multiple positive interactions over time among the stakeholders. In exchange, generally, only one rupture in a relation is sufficient for distrust to

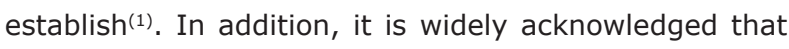
it usually demands more work to eliminate distrust than to try and enhance trust. This research departs from the premise that this is the case for the relation between head nurses and other health workers in the complex and high-pressure context of health service work.
According to research, in this environment, authoritarian leadership predominates ${ }^{(2)}$, the organizational climate is described as strict and intolerant and abusive behaviors are legitimized as a habitual form of relating ${ }^{(3)}$.

Distrust is relevant because, when present in the relation with the head, a vicious circle is produced. When distrusting, the worker perceives everything the head says and does as non credible and threatening and, thus, probably reduces communication with him, which makes it difficult to overcome negativity and again believe in the leader(1). When communication 
breaks up, it becomes practically impossible to exert authentic/participatory leadership in nursing, that is, truly effective leadership (2).

Moreover, studies show that workers do not pay the same level of attention and importance to positive and negative events at work. Instead, they tend to remember negative incidents involving heads more and describe them more intensely ${ }^{(4)}$. This negative trend has been confirmed in research about trust and distrust ${ }^{(1)}$. Studies show that situations of trust erosion are perceived as more outstanding than situations that build trust, and that trust erosion incidents influence people's judgments more than trust building incidents, even if the latter are larger(5).

Based on these antecedents, it should not cause estrangement that researchers(6) have found distrust in heads to be easier than trust. In fact, they pose that, as it is practically impossible for heads to make all workers feel satisfied, it is more beneficial for heads to focus on avoiding the development of their workers' distrust and on breaking up the mechanisms that maintain it. Therefore, this study is based on the need to develop nursing leadership skills, specifically showing those behaviors that arouse distrust towards head nurses, so that, on the one hand, they can consider avoiding them in their hospital management(2) and, on the other, so that they can understand what personal and professional characteristics should be cultivated so as not to be perceived as unreliable.

A relative consensus exists among researchers, who define trust as one stakeholder's willingness to be vulnerable to another stakeholder's actions, based on the expectation that the other will perform an action that is important for who trusts, independently of the ability to monitor or control him/her ${ }^{(1,7)}$. About distrust, on the other hand, no consensus definition exist but, in general, it is considered as the negative expectation of the trusting person about the other person's conduct ${ }^{(1)}$. According to some authors(8), one important characteristic would be that distrust only emerges where trust has previously existed, so that it is a product of betrayal. Betrayal is the rupture of expected trust in a relation, it is a voluntary act by the person one trusts and intends to damage the person who is trusting ${ }^{(9)}$. Consequently, probably, a scale is produced that increased the interpersonal distance between the stakeholders ${ }^{(10)}$

Traditionally, trust and distrust have been considered extreme ends of a single continuum and trust erosion has simply been supposed to be the inexistence of trust or its opposite. However, in line with the concept of distrust as betrayal, recently, some experts ${ }^{(10)}$ have defended the idea that, although trust and mistrust are related processes, they should be considered independent constructs and, what is important, in some cases, triggered by different antecedents. In summary, the dynamics of trust erosion is not opposed to trust building. In line with the above, research gives evidence that different brain areas are involved in each case ${ }^{(11)}$.

Of interest to this paper is that the above gives rise to the possibility that different components of the head's perceived trustworthiness can contribute more to the construction of trust than to trust erosion and viceversa.

The broadest and most systematic recent research efforts on trust in the leader is probably the model that sustains that trust in the leader largely depends on the leader's perceived trustworthiness, specifically on the leader's perceived capacity, benevolence and integrity dimensions $^{(7)}$.

The dimensions of trustworthiness can be defined as follows ${ }^{(5,9)}$ : the capacity dimension has been defined as a group of skills and competences that allow a person to exert influence within a specific domain. In this specific domain (some technical area for example), the trustworthy person can be highly competent for good management; in a different area (interpersonal communication for example), his/her capacity can be limited and (s)he may not be trustworthy in that domain. The integrity dimension involves the perception that the trustworthy person adheres to a set of ethical principles the trusting person finds acceptable. A sense of integrity involves both the adherence to and acceptability of these principles, given that, if the trusting person does not accept a set of principles the trustworthy person adopts, the trustworthy person would not be considered upright. Examples of head nurses' conducts in hospitals would be: not showing favoritism to employees, impartiality to assign benefits and sincerity(12). The benevolence dimension has been defined as the belief that the trustworthy person wants to do good to the trusting person, leaving aside personal profit. Benevolence suggests that the trustworthy person has a specific bond with the trusting person, reflected in the perceived positive orientation of the trustworthy towards the other person. Examples of head nurses' conducts in hospitals would be: treating the staff well, highlighting positive aspects of work, understanding employees' problems and supporting them(12).

Although comprehensive models of trustworthiness dimensions have been developed, few studies 
have addressed the relative weight of these three trustworthiness dimensions in trust erosion. Given that trust and mistrust processes differ, it has been posed that the three dimensions of trustworthiness (capacity, integrity and benevolence) probably affect trust erosion differently. In fact, research ${ }^{(1,4)}$ results have revealed this trend.

Employees probably start a relation with the head, a priori expecting some level of perceived integrity and capacity, based on the belief that the organization chooses heads who demonstrate some degree of capacity in the mastery of their role and who show a great sense of integrity ${ }^{(4)}$. This expectation can relate to the fact that many relations between heads and workers occur inside institutions, in which employees hold some level of institutional trust. Thus, leaders who demonstrate conducts that reaffirm their integrity or capacity may not inspire a particularly high level of trust $^{(4)}$. If leaders do not rise up to these expectations, however, they will act in ways that raise doubts, about their supposed capacity or integrity, probably, this will significantly contribute to trust erosion.

According to this perspective, leaders' behaviors that reflect integrity and capacity can be perceived as the most basic requisites workers would expect from their leader. More specifically, given that the workers may consider the heads' integrity and capacity reflecting conducts as expected and may even ignore them, they may not particularly contribute to trust building. On the other hand, if heads do not demonstrate integrity and capacity reflecting behaviors, it is quite probable that workers observe this fact and, thus, that trust is eroded(4). $^{(4)}$

Given that distrust is closely related with betrayal, however, heads' behaviors that reflect lack of capacity would not be considered betrayals, given that the trusted person does not intentionally aim for damage ${ }^{(9)}$. Hence, distrust resulting for heads' lack of capacity may hardly be relevant.

In view of the above and the still fragmented understanding about when and how trust is eroded(7,11), as well as the relative lack of research about interpersonal distrust ${ }^{(11)}$, all the more in the nursing context, two research aims were set: (a) to identify the main types of conducts or categories associated with distrust in head nurses and (b) to determine which of the perceived trustworthiness dimensions in the head can more frequently damage trust in the hospital context. Regarding the latter, the hypothesis is put forward that health professionals will recall and report significantly more situations reflecting head nurses' lack of integrity than their lack of benevolence.

\section{Method}

A descriptive research design was chosen and the critical incident technique was used for data collection. A phenomenological focus was adopted to analyze the contents of the semistructured interviews held. The research was accomplished at a high-complexity public teaching and research hospital with more than 2,500 employees in the third largest city of Chile. Data collection went from September 2009 until December 2010.

\section{Participants}

Ninety employees participated, 26,7 \% of whom were nurses and $73,3 \%$ technicians with a higher education degree. Women corresponded to $86 \%$. These professionals were chosen because they work most frequently with head nurses in hospitals. The adopted selection method was random sampling, according to the workers' available time when the researchers visited the clinical services. During all visits, there were cases of employees who refused to participate. The interviews were held in private places, mostly offices available at the services. Participants worked at nine different clinical services.

Inclusion criteria were as follows: workers should be nurses or paramedic technicians, work at a clinical service in a hospital, with at least one year of experience at that service. This guaranteed a relation of dependence between the participants and some heads and knowledge about interpersonal relations of trust with head nurses.

\section{Ethical concerns}

Approval for the research project was obtained from the Institutional Review Board at the Universidad de Concepción. Authorization from hospital management was obtained before the start of data collection. Participants received an informed consent letter they were expected to sign before the interview. In this letter, anonymity and secrecy of their answers were guaranteed, and minimal demographic data were requested.

\section{Instrument}

In accordance with specialized literature ${ }^{(13-14)}$, a semistructured interview was elaborated to obtain critical incidents. In the instructions, they were asked 
to think of a direct head and evoke a significant incident that led to trust and another that led to distrust in their head. In this paper, the analysis of answers to only one question will be presented. The specific question was: "Can you describe a situation you experienced in your work lately and which made you feel some degree of distrust in your direct head?". Ten pilot interviews were held to analyze whether the question was correctly understood, revealing no doubts. Then, questions were asked for participants to describe the experience with as much detail as possible and elaborate on their experience.

\section{Procedure}

The interviewers were nursing and psychology students who were previously prepared as interviewers to use the critical incident technique, especially due to the fact that, in the pilot interviews, it was observed that, in response to the proposed theme, some interviewees relived intense negative experiences. The preparation included written material, analysis of interview cases and advice on how to cope with the interviewees' emotional condition. The interviews were held at the employees' workplace, guaranteeing their privacy. Duration was approximately 20 to 25 minutes and the same interviewers wrote down the answers on paper during the interview and then transcribed them to a computer.

\section{Content analysis of the incidents}

The researchers were responsible for systemizing the data. Out of 90 interviews, 14 interviewees did not mention incidents of distrust, so that the reports of 76 incidents obtained from the interviews were literally transcribed. During a first reading, it was determined whether the contents fully adhered to the research theme. In this phase, 15 incidents were discarded because they did not comply with inclusion requirements.

The coding process involved three phases. First, events were ranked according to the type of conducts the head displayed. One researcher performed this ranking, following by the second researcher's independent assessment. Differences were discussed until reaching a consensus. Then, to reduce the number of categories, both researchers independently elaborated larger groups of categories, differences were discussed and a consensus was achieved. Then, it was calculated how many times each category was mentioned and the result table was elaborated.

In the third phase, the relation between the categories found and the trustworthiness dimensions was determined. The reference framework included but was not strictly limited to the theoretical framework by Burke et al.(7). Data were approached looking for any additional categories that would emerge. In this case too, first, one researcher performed this process, followed by the second researcher's independent assessment and discussion of differences.

\section{Results}

Sixty-one critical incidents of distrust towards head nurses were obtained from the interviews with 90 professionals. Content analysis revealed 14 categories of conducts that eroded the workers' trust, which in turn constituted five groups. Each of the 14 categories of distrust events contains subcategories, showing that various situations exist that can arouse the workers' distrust (Table 1).

Table 1 - Frequency and percentage of group and categories of trust eroding conducts

\begin{tabular}{ll}
\hline \multicolumn{1}{c}{ Group of categories } & \multicolumn{1}{c}{ Categories } \\
\hline 1. Mistreatment by the Head. & $\begin{array}{l}\text { 1.1. Mistreatment in Public: Calling the worker's attention in public, raising one's } \\
\text { voice, disqualifying, treating as a liar, making one look bad before peers and } \\
\text { patients. }\end{array}$ \\
$\begin{array}{l}\text { 1.2. Does not Forgive: Showing grudge for years or vindictive conducts for having } \\
\text { talked to the superior head. }\end{array}$ \\
$\begin{array}{l}\text { 1.3 Speaking Badly of the Employee: Telling negative opinions about somebody to } \\
\text { other people, telling things one told him/her in secret to other people, commenting } \\
\text { on the way of working to other people. } \\
\text { 1.4. Not Listening to Reasons: Not wanting to listen to an argument, not wanting to } \\
\text { talk about a problem, making decisions without listening to what happened. } \\
\text { Total category } 1: 23 \\
37.7 \%\end{array}$ \\
(continue...)
\end{tabular}


Table 1 - (continuation)

\begin{tabular}{|c|c|c|c|}
\hline Group of categories & Categories & Frequency & $\%$ \\
\hline \multirow[t]{4}{*}{ 2. Lack of Support to Worker } & $\begin{array}{l}\text { 2.1. Lack of Support: Not warning or informing, impairing secretly, preferring to } \\
\text { help somebody else, not doing anything to solve a personal problem. }\end{array}$ & 4 & \\
\hline & $\begin{array}{l}\text { 2.2. Not Taking Care of the Employee's Health: Not following a procedure in an } \\
\text { accident, bothering because a medical leave is requested. }\end{array}$ & 2 & \\
\hline & $\begin{array}{l}\text { 2.3. Not Giving Permission for Something Special: Devaluing personal problems, } \\
\text { requiring that work be prioritized over children, not authorizing a permit in case of } \\
\text { urgency. }\end{array}$ & 6 & \\
\hline & Total category 2: 12 & & $19.7 \%$ \\
\hline \multirow[t]{3}{*}{ 3. Not Believing in the Worker } & $\begin{array}{l}\text { 3.1. Not Trusting in the Employee's Work: Permanently reviewing the work done, } \\
\text { not authorizing procedures, being judged negatively for one single fact, ignoring } \\
\text { the work done, not informing at the right moment whether work was done badly, } \\
\text { believing that one is not responsible. }\end{array}$ & 5 & \\
\hline & $\begin{array}{l}\text { 3.2. Does Not Believe in what the Employee Says: Generally, because of } \\
\text { misunderstandings, blaming the employee for something and not believing in him/ } \\
\text { her, doubting what (s)he affirms. }\end{array}$ & 5 & \\
\hline & Total category 3: 10 & & $16.4 \%$ \\
\hline \multirow[t]{3}{*}{ 4. Lack of Objectivity by the Head } & $\begin{array}{l}\text { 4.1. Favoritism: Preferring to help friends, choosing people out of convenience, } \\
\text { protecting close people, granting special benefits to some. }\end{array}$ & 5 & \\
\hline & $\begin{array}{l}\text { 4.2. Being Guided by Rumors: Trend to ask others and not talking with the } \\
\text { stakeholder, consider other people's opinions as facts, not seeking objective data. }\end{array}$ & 3 & \\
\hline & Total category 4: 8 & & $13.1 \%$ \\
\hline \multirow[t]{5}{*}{$\begin{array}{l}\text { 5. Low Level of Commitment by } \\
\text { the Head }\end{array}$} & $\begin{array}{l}\text { 5.1. Dishonesty for one's Own Benefit: Hiding one's errors and blaming the other, } \\
\text { informing somebody else's idea as one's own, asking to lie so as not to impair } \\
\text { oneself. }\end{array}$ & 3 & \\
\hline & $\begin{array}{l}\text { 5.2. Not Complying with one's Work: Not wanting to cooperate with other people } \\
\text { for one's own convenience, asking hidden favors from the head, not doing what is } \\
\text { correct so as not to bother one's superiors. }\end{array}$ & 3 & \\
\hline & $\begin{array}{l}\text { 5.3. Low Commitment to the Service: Not committing to one's service, not taking } \\
\text { care of the service's resources. }\end{array}$ & 2 & \\
\hline & Total category $5: 8$ & & $13.1 \%$ \\
\hline & Total number of critical incidents & 61 & \\
\hline
\end{tabular}

When relating the groups of categories found with the trustworthiness dimensions proposed in literature about the theme, two dimensions were found that are involved in the distrust events the employees reported: integrity and benevolence. No incidents were related to the competency dimension. In exchange, one group of categories did not adjust to the expected dimensions and a new dimension was proposed: Trend to Distrust (Table 2).
Table 2 - Percentages in trustworthiness dimensions and group of categories

\begin{tabular}{lcl}
\hline \multicolumn{1}{c}{ Dimensions } & Percentage & Group of categories \\
\hline Integrity & $63.9 \%$ & $\begin{array}{l}\text { Mistreatment by the Head } \\
\text { Lack of Objectivity by the Head } \\
\text { Low Level of Commitment of } \\
\text { the Head }\end{array}$ \\
Benevolence & $19.7 \%$ & Lack of Support to Worker \\
Trend to Distrust & $16.4 \%$ & Not Believing in the Worker \\
\hline
\end{tabular}




\section{Discussion}

Work in public hospitals has been posed as complex and demanding. Also, interpersonal conflicts can arise that can easily lead to the erosion of employees' trust in head nurses. Therefore, the goal proposed in this research was to identify the most frequently mentioned types of conducts that erode health workers' trust, as well as to determine the main trustworthiness dimension involved.

The category most frequently mentioned with regard to the erosion of trust in the head nurse was "Mistreatment in Public" by the head. In these cases, the interviewees probably experience a profound sense of humiliation and powerlessness. These conducts probably reveal the head nurses' lack of emotional control and can be interpreted as lack of respect for the worker as a person, significantly harming his/her self-esteem. This conduct category can be labeled as a severe case of an abusive leader who exerts occupational violence and, thus, not only causes severe damage for the worker's psychological wellbeing, but also generates a negative job climate at health services.

In second place, with quite a lower percentage, came "Not Giving Permission for Something Special" to the worker. In this case, the head is perceived as ignoring or devaluating the worker's needs, accompanied by the impression of lack of sensitivity and concern with the workers. Three categories rank third: "Favoritism" for some workers, "Not Trusting in the Employee's Work" and "Does not Believe in what the Worker Says". Favoritism refers to the establishment of personal loyalties without any relation with the worker's performance. This could be understood as bonds that help to protect those involved. Earlier studies shows that this is a relevant practice at health centers ${ }^{(12)}$. The consequences of this practice probably result in profound feelings of injustice. Finally, the two remaining categories raise the problem that heads distrust the worker, that workers are not seen as credible, probably leading to uncertainty and a felt lack of support by the heads.

Concerning the hypothesis raised, the most frequently mentioned trustworthiness dimension in the distrust incidence was the head's lack of integrity. These results are in line with previous studies(5) and show that the trustworthiness dimensions are not equally important, and that their relevance varies depending on whether the situation is of trust or distrust.

It is estimated that the relevance of the critical incidents related with the head's lack of integrity would support the concept of distrust as betrayal(9). This is due to the fact that the distrust incidents were characterized by the perception that the head damaged the employees, given that basic expectations were not complied with, expectations linked with central values like respectful and fair treatment for example. These results show that head nurses' ethical behavior is very important. According to the bibliographic review ${ }^{(1)}$, nonethical behavior will probably produce a dynamics in the relation with the head which makes the employees restrict communication with their head and severely affects health services' organizational climate.

One result that was coherent with the hypothesis raised and with the studies reviewed( ${ }^{(9)}$ was that the interviewees did not mention distrust incidents linked with the heads' lack of capacity. This result also supports the concept of distrust as betrayal, as the head's lack of capacity would not be related with distrust.

One unexpected result was the emergence of the dimension Trend to Distrust, corresponding to the group of categories "Not Believing in the Worker". This dimension did not correspond to any of the three dimensions considered in the study. This could be interpreted as follows: head nurses tend to distrust their employees, so that the latter feel devalued and that their head's attitude impairs their self-esteem, which in turn entails their head's attitude of distrust. Although this new dimension was not very frequently mentioned, further research is considered due to inquire whether it should be included among the trustworthiness dimensions of leaders.

The results obtained in this research entail practical implications. The main one is that nursing heads should focus their efforts on preventing episodes of distrust with the workers. Given that distrust events are more reminded and exert a greater emotional impact on the workers $^{(1,5)}$, the heads should be very aware of the conducts that probably lead to trust erosion and concerned with avoiding or limiting them. As research shows ${ }^{(2)}$, nursing professionals should communicate well with their team members and exert authentic/ participatory leadership. Based on the obtained results, ethical behavior stands out, with sensitivity to the moral dilemmas they need to face when dealing with the workers, demonstrating a great sense of integrity, acting so as to safeguard the principles of respect and justice (impartiality) towards the employees they are in charge of. Finally, based on the above, permanent 
efforts are needed to prepare leaderships. Authors pose that these efforts should start in the early stages of nursing education(2).

From a methodological perspective, it is important to mention that the theme addressed is delicate for the workers and that achieving their cooperation was complex. Therefore, it is considered fundamental that the interviewers know how to create adequate conditions. The theme includes a strong emotional component, so that, on several occasions, some degree of emotional containment of the participants by the interviewers was prudent.

The main limitation of this research was that the collected incidents correspond to the reality of a single public hospital, which limits the generalizability of results. In this sense, replication in other contexts is considered convenient for future studies.

\section{Conclusion}

The relation between head nurses and employees is exposed to situations that can erode mutual trust. The primary contribution of this research was to identify the most frequent types of incidents that, according to the workers, can arouse distrust in their head ("Mistreatment in Public", "Not granting Permission for something Special"). After identifying the critical incidents, the role of the head is to prevent them from happening, in view of clear signs that repairing trust is a difficult process. The second contribution was the support for the hypothesis that the incidents were mainly related with the integrity dimension of leadership. From a theoretical perspective, this offers evidence that distrust could be conceptualized as the fruit of a perceived betrayal. From a practical viewpoint, it means that head nurses should be concerned with permanent education to strengthen awareness of the ethical dimension in their relation with the employees, particularly with showing respect and sensitivity towards the workers' problems and fairness or impartiality towards them.

\section{References}

1. Keyton J. Distrust in leaders: dimensions, patterns, and emotional intensity. J Leadership Org Studie. 2009;16(1):6-18.

2. Lanzoni GMM, Meirelles, BHS. Leadership of the nurse: an integrative literature review. Rev. Latino-Am. Enfermagem. 2011;19(3):651-8.
3. Castellón AMD. Violencia laboral en enfermeras: explicaciones y estrategias de afrontamiento. Rev. Latino-Am. Enfermagem 2011;19(1):156-63.

4. Dasborough M. Cognitive asymmetry in employee emotional reactions to leadership behaviors. Leadership Q. 2006;17:163-78.

5. Lapidot Y, Kark R, Boas S. The impact of situational vulnerability on the development and erosion of followers trust in their leader. Leadership Q. 2007; 18:16-34.

6. Dirks K, Skarlicki D. Trust in leaders: Existing research and emerging issues. In: Kramer $\mathrm{R}$, Cook $\mathrm{K}$, editors. Trust and Distrust in Organizations. New York: Rusell Sage Foundation; 2004. p. 21-40.

7. Burke C, Sims D, Lazzara E, Salas E. Trust in leadership: A multi-level review and integration. Leadership Q. 2007;18(6):606-32.

8. Bies R, Tripp T. Beyond trust: "Getting even" and the need for revenge. In: Kramer $\mathrm{R}$, Tyler $\mathrm{T}$, editors. Trust in organizations: frontiers of theory and research. Thousand Oaks: Sage; 1996. p. 246-60.

9. Chan ME. "Why Did You Hurt Me?" Victim's Interpersonal Betrayal Attribution and Trust Implications. Rev Gen Psychol. 2009;13(3):262-74.

10. Sitkin S, Roth N. Explaining the limited effectiveness of legalistic "remedies" for trust/distrust. En: Kramer RM, editor. Organizational trust: A reader. New York: Oxford University Press; 2006. p. 295-330.

11. Dimoka A. What does the brain tell us about trust and distrust? Evidence from a functional neuroimaging study. MIS Q. 2010;34(2):373-96.

12. Yáñez R, Loyola G, Huenumilla F. La confiabilidad en el Líder: Un estudio sobre las enfermeras jefes de un hospital. Cienc Enferm. 2009;15(3):77-89.

13. Chell E. Critical incident technique. In: Cassell C, editor. Essential Guide to Qualitative Methods in Organizational Research. Londres: Thousand Oaks; 2004. p. 45-60.

14. Yáñez $R$, López-Mena $L$, Reyes F. La técnica de incidentes críticos: Una herramienta clásica y vigente en enfermería. Cienc Enferm. 2011;17(2):27-36.

Received: Mar. 29 2011 Accepted: Dec. 19 2011 